\title{
Nutrients Utilization and Growth by Yankasa Rams Fed Cowpea Husk, Ureaand Molasses Treated Maize Cobs
}

\author{
Adamu B. ${ }^{1}$, Abdullahi, $\mathbf{S}^{2}$. Abdullah, $\mathbf{M}^{3}$ \\ ${ }^{1}$ Adamawa State Polytechnic Yola \\ ${ }^{2}$ Ministry of Livestock and Nomadic Settlement, Yola, Adamawa State \\ ${ }^{3}$ Adamawa State Polytechnic Yola
}

\begin{abstract}
This study find out nutrients utilization and growth by yankasa rams fed cowpea husk, molasses treated maize cobs. Seventy days feeding trial was conducted to determined the nutrients utilization and growth by Yankasa rams fed cowpea husk, urea and molasses treated maize cobs. Twelve growing Yankasa rams aged between 8-12 months were subjected to four dietary treatments in a complete randomized block design (CRBD). The four dietary treatment were $T_{1}\left(4 \mathrm{~kg}\right.$ urea ensiled maize cobs and cowpea husk) only, $T_{2}$ (4kg urea and $2 \mathrm{~kg}$ molasses ensiled maize cobs with cowpea husk, $T_{3}$ (4kg urea and $4 \mathrm{~kg}$ molasses ensiled maize cobs with cowpea husk) $T_{4}$ (4kg urea and $6 \mathrm{~kg}$ molasses ensiled maize cobs with cowpea husk). The result of the chemical composition shows the dry matter, crude protein, crude fibre, Ash, Ether extract, nitrogen free extract values were 96.0\% -97.0 \%(DM), 9.0-12.2\% (CP), 4.0-5.5\% (CF), 8.5$10.0 \%$ ash, 1.1-2.4\% (EE), 68.70- 73.00\% (NFE), ME,2979.35-3118.90Kcal/kg for $\mathrm{T}_{1}, \mathrm{~T}_{2}, \mathrm{~T}_{3}$, and $\mathrm{T}_{4}$. The proximate composition of maize cobs were $98.5 \%$ (DM), 3.8\% (CP) $10.0 \%$ (CF) $1.1 \%$ (EE), 1.2\% Ash; 80.0\% NFE 76.1\%(NDF) 49.9\% (ADF), 3.06Kcal/kg. The total feed intakes were $118.90-128.70 \mathrm{~g} / \mathrm{h} /$ day. The feed conversion ratios were from $10.62-0.860$. The final weight gains were $28.00 \mathrm{~kg}$ 30.04kg. Avearage Daily Live weight gain were 86.56 - 115.78g/h/day. The nutrients intake values were 118.84-127.74 (DMI) g/h/day, $116.42-119.41 \mathrm{~g} / \mathrm{h} / \mathrm{d}(\mathrm{OMI}), 119.69-128.59 \mathrm{~g} / \mathrm{h} / \mathrm{d}$ (CPI), 119.66-128.56g/h/d (CFI) and 119.70-128.68 Ash. While the nutrients digestibility were from 47.88- 59.43\% (DMD), 46.29-56.72\% (CPD), 36.06- 47.13EED, 32.72-65.71 CFD, 39.58-44.25\% ASHD, 39.2129.69(NFED). The study revealed that treatment four (4kg urea and $6 \mathrm{~kg}$ molasses) gave significant higher dry matter intake and live weigh gain in Yankasa rams.
\end{abstract}

Keywords: Cowpea Husk, Urea, Molasses, Maize Cobs and Yankasa Rams

\section{Introduction}

The bulk of the ruminants feeds comes from forages, grasses, shrubs and trees, the shrubs and grasses are only vegetative and available as animal feeds in the raining season while the trees which serves as browse plants are available throughout the year which decline rapidly in quality during the dry season Ademosum (1973). The need to search for cheaper alternative quality feed has become necessary, this can be carried out through various methods employed to upgrade crops residues by ensiling the material with various additives, which will lead to better utilization of the nutrients for rumen micro-bial growth and result in improve digestibility, increase surface area of lingocellulose due to higher nitrogen retention Khan et.al (2004) which might have resulted in increased in accessibility to microbial attack in maize cobs ensiled with molasses and cowpea husks. Molasses is an important by-product of sugar cane industry and a good source of fermentable carbohydrate (sucrose) can be used to capture $\mathrm{NH}_{3}-\mathrm{N}$ in urea treated materials. Acidification of molasses may further help enhance the nitrogen capture in urea treated maize cobs and their feeding value for sheep. (Sarwaret.al 2005).

\section{Materials and Methods}

Experimental site

The study was conducted at the Research Farm of the ModibboAdama University of Technology, Yola, Adamawa State, Nigeria. The area is located between latitude $9^{\circ}$ and
$11^{0}$ north and is on longitude $11^{\circ}$ and $14^{\circ}$ east of the meridian. This is a tropical area with climate marked by dry and rainy seasons, the rainy season commences in April and end in late October and the dry season start from late October and ends in March (Adebayo and Tukur, 1999).

\section{Experimental animals}

Twelve growing Yankasa Rams aged between 8-12 months were used for the study. They were de-wormed and treated for internal and external parasites. The animals were subjected to pre-experimental adaptation for two weeks, and were subjected to four dietary treatments in a complete randomized block design. $\left(\mathrm{T}_{1}\right) 4 \mathrm{~kg}$ urea ensiled maize cobs with cowpea husk only. $\left(\mathrm{T}_{2}\right) 4 \mathrm{~kg}$ urea and $2 \mathrm{~kg}$ molasses ensiled maize cobs with cowpea husk. $\left(\mathrm{T}_{3}\right) 4 \mathrm{~kg}$ urea and $4 \mathrm{~kg}$ molasses ensiled maize cobs and cowpea husk. ( $\left.\mathrm{T}_{4}\right) \quad 4 \mathrm{~kg}$ urea and $6 \mathrm{~kg}$ molasses ensiled maize cobs with cowpea husk. The feeds was mixed and fed as complete ration.

\section{Procurement and processing of experimental diets}

The cowpea husks and the maize cobs were procured from local farmers in Jimeta. Yola Adamawa State Nigeria and stored in bags. Before ensiling, maize cobs was dried and crushed $2 \mathrm{~cm}$ particle size, before ensiling, the treated maize cobs were pressed for air exclusion, knotted to achieve anaerobic condition ensiled for 15 days as documented by Khan et al (2004). Although ensiling from 21 days was carried out in the present studies to achieve better urea hydrolysis. $4 \mathrm{~kg}$ of urea was dissolved in one hundred litres of water and one hundred $\mathrm{kg}$ of maize cobs was submerged 


\section{International Journal of Science and Research (IJSR) \\ ISSN (Online): 2319-7064}

Index Copernicus Value (2015): 78.96 | Impact Factor (2015): 6.391

in the solution and tied in an air tight polythene bags for 21 days in treatment one. Treatment two, $4 \mathrm{~kg}$ of Urea, $2 \mathrm{~kg}$ of molasses was dissolved in one hundred litres of water and one hundred $\mathrm{kg}$ of maize cobs submerged and also tight in polythene bags for $21^{\prime}$ days. Treatment three, $4 \mathrm{~kg} \mathrm{~kg}$ of urea, $4 \mathrm{~kg}$ of molasses was dissolved in one hundred litres of water and one hundred $\mathrm{kg}$ of maize cobs immersed and transferred to a polythene bags ensiled for 21 days. Treatment four, $4 \mathrm{~kg}$ of Urea, $6 \mathrm{~kg}$ of molasses was dissolved in one hundred litres of water and one hundred $\mathrm{kg}$ of maize cobs submerged and transferred to a polythene bags ensiled for 21 days. The material ensiled was covered tightly to prevent seepage and air entrance.At the beginning of ensiling aerobic and facultative organisms survive on the oxygen trapped in the silo or container producing carbon dioxide, water and heat. Once the oxygen is exhausted only anaerobic organisms can survive, this allowed the growth of acid forming and photolytic bacteria which convert carbohydrates into lactic acid, protein into ammonia, amines and amino acid which caused decreased $\mathrm{pH}$ in the ensiled materials which kills both yeast and mould, acidity continued to increase to a level where the acid producing organisms themselves are killed, at this $\mathrm{pH}$ and time ensiling is completed.

\section{Treatment and experimental design}

Complete randomized block design (CRBD) was used for the experiments. Twelve (12) Yankasa rams were randomly allocated to four treatments with three (3) replications. The main feeds for the experiment were cowpea husk, and maize cobs ensiled with $4 \%$ urea and graded levels of molasses.

Treatment $(1)=($ control) $4 \mathrm{~kg}$ urea ensiled maize cobs with cowpea husks mixed and fed as complete ration.

Treatment $(2)=4 \mathrm{~kg}$ urea ensiled maize cobs $+2 \mathrm{~kg}$ molasses with cowpea husks mixed and fed as complete ration.

Treatment (3) $=4 \mathrm{~kg}$ Urea ensiled maize cobs $+4 \mathrm{~kg}$ molasses with cowpea husks mixed and fed as complete ration.

Treatment $(4)=4 \mathrm{~kg}$ urea ensiled maize cobs $+6 \mathrm{~kg}$ molasses with cowpea husks mixed and fed as complete ration. $500 \mathrm{~g}$ of cowpea husk $+500 \mathrm{~g}$ ensiled maize cobs was mixed and fed as complete ration in all the treatment.

\section{Housing and management}

The research works consist of 12 growing Yankasa rams between the ages of 8-12 months. The experiment last for 3 months including the adaptation period, in which the rams were kept in pens with separate feeding and water troughs. The rams were dewormed and given multivitamins injection before the commencement of the experiment.The animals were fed twice daily 8:00am, in the morning and $4: 00 \mathrm{pm}$ in the evening; the remnant was measured to find out the rejected. The difference between the amounts of feed offered and the amount rejected was the amount consumed. The rams were weighed weekly using a spring balance for changes in weight.

\section{Experimental procedures}

\section{Feed intake}

Feeds where measured and offered to the rams, at 8.00 am in the morning and 4:00pm. Remnant was weighed daily before fresh feeds were offered for the determination of feed intake.

\section{Weight gain}

Initial live weight of the animals was recorded before the commencement of the experiment; subserviently the live weight gain was measured weekly. The initial live weight was subtracted from the final live weight gain to get the live weight changes

\section{Digestibility study}

Digestibility study was conducted after the feeding trial, an improvised metabolic bag and plastic containers were used for the collection of faeces and urine, four (4) rams were adapted in the metabolic cage for seven days, faeces and urine were collected for fourteen days. An improvised bags were used to trap faeces from individual rams, total faecal output was measured daily using a weighing scale, the faeces were bulked and at the end of the collection period $10 \%$ sub samples were dried, milled and stored in sealed and labeled bottle before analysis. The urine was collected with the aid of a slanted groove attached to the cages which allowed the urine to flow into a plastic container; the volume was measured using a graduated laboratory cylinder, urine was collected into a bottle acidified with $10 \mathrm{ml}$ concentrated sulphuric acid and store in a refrigerator at $4^{0} \mathrm{C}$ for ammonia concentration in urine and urine $\mathrm{pH}$ analysis.

\section{Chemical analysis of the experimental diets}

Proximate analysis of ensiled maize cobs and cowpea husk, nitrogen in the urine was carried out using the procedure outlined by AOAC, (1990) to determine the dry matter (DM), crude protein $(\mathrm{CP})$, crude fiber $(\mathrm{CF})$, ether extract (EE) and ash (ASH)

\section{Statistical analysis}

Data obtained was subjected to analysis of variance (ANOVA) and differences between mean separated Steel and Tories (1980) .The results was analyzed using SPSS version 17.

\section{Result}

Table 1: Proximate composition of the experimental ingredients

\begin{tabular}{|c|c|c|c|}
\hline Constituent (\%) & $\begin{array}{c}\text { Maize } \\
\text { cob }\end{array}$ & $\begin{array}{c}\text { Ensiled Maize } \\
\text { Cobs }\end{array}$ & $\begin{array}{c}\text { Cowpea } \\
\text { Husks }\end{array}$ \\
\hline Dry Matter (DM) & 98.5 & 97.0 & 98.0 \\
\hline Crude protein (CP) & 3.8 & 12.2 & 12.0 \\
\hline Crude Fiber (CF) & 10.0 & 4.0 & 10.0 \\
\hline Ether Extract (EE) & 1.1 & 1.1 & 2.90 \\
\hline Ash & 1.2 & 10 & 7.2 \\
\hline $\begin{array}{c}\text { Nitrogen Free Extract } \\
\text { (NFE) }\end{array}$ & 80.0 & 68.70 & 65.7 \\
\hline $\begin{array}{c}\text { Neutral Detergent fiber } \\
\text { (NDF) }\end{array}$ & 76.1 & 54.2 & 64.3 \\
\hline Acid detergent fiber (ADF) & 49.9 & 53.8 & 43.5 \\
\hline ME (Kcal/Kg) & 3.06 & 4.08 & 3.01 \\
\hline
\end{tabular}

Proximate composition of the experimental ingredients, maize cobs, ensiled maize cobs $\&$ Cowpea husk:

The maize cobs contains 97.0 DM ensiled maize cobs 98.098.5\% DM cowpea husk obtained in the present study which 


\section{International Journal of Science and Research (IJSR) \\ ISSN (Online): 2319-7064}

Index Copernicus Value (2015): 78.96 | Impact Factor (2015): 6.391

was contrary to the value of $92.40 \% \mathrm{DM}$ obtained by Ibrahim (2007).

The crude fiber of $10.0 \%$ for maize cobs, $4.0 \% \mathrm{CF}$ for ensiled maize cobs and $10.0 \%$ for cowpea husks was lower than the values of $35.1 \% \mathrm{CF}$ obtained and reported by Toledo et al (1990). The Ash content in the present study was $1.2 \%$ for maize cobs, $10.0 \%$ for ensiled maize cobs and $7.2 \%$ for cowpea husk subserviently, comparable to the value of maize cobs of $1.2 \%$ obtained and reported by Agreheore (2001), but a little higher than the value of 5.63\% reported by Ribanre (2007), and closely comparable to $11.1 \%$ obtained for ensiled maize cobs reported by A.A.J (2006).

Table 2: Chemical composition of maize cobs ensiled with urea and graded level of molasses

\begin{tabular}{|lcccl|}
\hline \multirow{2}{*}{ Constituent (\%) } & $T_{L}$ & $T_{2}$ & $T_{z}$ & $T_{4}$ \\
& $4 U$ & $4 u+2 m$ & $4 u+4 m$ & $4 u+6 m$ \\
\hline $\mathrm{DM}$ & 97.0 & 96.5 & 96.40 & 96.0 \\
\hline $\mathrm{CP}$ & 12.2 & 11.0 & 9.5 & 9.0 \\
\hline $\mathrm{CF}$ & 4.0 & 5.0 & 5.3 & 5.5 \\
\hline Ash & 10 & 9.8 & 9.8 & 8.5 \\
\hline $\mathrm{EE}$ & 1.1 & 1.2 & 2.1 & 2.4 \\
\hline $\mathrm{NFE}$ & 68.70 & 69.70 & 71.01 & 73.00 \\
\hline $\mathrm{ME}(\mathrm{Kcal} / \mathrm{kg})$ & 2979.35 & 2978.55 & 3042.46 & 3118.90 \\
\hline
\end{tabular}

Chemical composition of maize cobs, ensiled with urea and graded level of molasses

The result shows that the dry matter contents in $\mathrm{T}_{1}$ was $97.0 \%$ DM (4kg urea only) while $96.5 \% \mathrm{DM} \mathrm{T}_{2}$ (4kg urea and $2 \mathrm{~kg}$ Molasses), $96.40 \% \mathrm{DM}$ (4kg urea and $4 \mathrm{~kg}$ Molasses) $\mathrm{T}_{3}$ while $96.0 \% \mathrm{DM}$ was obtained in $\mathrm{T}_{4}$ (4kg urea and $6 \mathrm{~kg}$ Molasses). The result showed a higher DM in $\mathrm{T}_{1}$ followed by $T_{2}, T_{3}$ and $T_{4}$ being the lowest. The DM content was little higher to the value of $92.40 \%$ obtained and reported by Ibrahim (2007). The higher values might be attributed to variation in soil fertility, harvesting and curing which usually affect the chemical composition. The CP of $12.2 \%$ was obtained in $\mathrm{T}_{1}, 11.0 \%$ in $\mathrm{T}_{2}, 9.5 \%$ in $\mathrm{T}_{3}$ and $9.0 \% \mathrm{~T}_{4}$ the $\mathrm{CP}$ value were contrary to the values of $18.00 \%$ obtained and reported by Fadiyimuet al (2011). The fibre content was $4.0 \%$ in $\mathrm{T}_{1} 5.0 \%$ in $\mathrm{T}_{2}, 5.3 \%$ in $\mathrm{T}_{3}$ and $5.5 \%$ in $\mathrm{T}_{4}$ far below the $30.0 \%$ reported by Dimas, (2012) which is indication of characteristic nature of plants when harvested at the late stage of growth. The ether extract was $2.4 \% \mathrm{~T}_{4}$ while $2.1 \% \mathrm{~T}_{3}, 1.2 \% \mathrm{~T}_{2}$ and $1.1 \% \mathrm{~T}_{1}$ been the lowest in the diet, the nitrogen free extract in $\mathrm{T}_{1}$ was the lowest $68.70 \%$, followed by $69.70 \% \mathrm{~T}_{2}, 71.0 \% \mathrm{~T}_{3}$ and $73.00 \% \mathrm{~T}_{4}$ been the highest which was contrary to the findings of (Sarwar et al 2005 ), ash content in treatment diets, was $10.0 \% \mathrm{~T}_{1} 9.8 \%$ in $\mathrm{T} 2$ and $\mathrm{T} 3,8.5 \%$ in $\mathrm{T} 4$.

Table 3: Growth performance of Yankasa rams fed cowpea husk, urea and molasses treated maize cobs.

\begin{tabular}{|l|l|l|l|l|l|}
\hline \multicolumn{1}{|c|}{ Treatment } \\
\hline \multicolumn{1}{|c|}{ Parameters } & \multicolumn{1}{c|}{ TI } & \multicolumn{1}{c|}{ T2 } & \multicolumn{1}{c|}{ T3 } & \multicolumn{1}{c|}{ T4 } & \multicolumn{1}{c|}{ LSD } \\
\hline Total Fed intake g/h/day & 118.90 & 121.40 & 124.10 & 128.70 & $11.34^{*}$ \\
Feed conversion ratio & 10.620 & 0.915 & 0.914 & 0.860 & $0.025^{* *}$ \\
Initial weight (kg) & 20.21 & 20.42 & 20.53 & 20.62 & $0.517^{\mathrm{NS}}$ \\
Final weight (kg) & 28.00 & 29.70 & 30.03 & 30.04 & $0.961^{\mathrm{NS}}$ \\
Total weight gain (kg) & 7.79 & 9.28 & 9.50 & 10.42 & $0.513 *$ \\
Average Daily Live Weight gain (g/d) & 86.56 & 103.11 & 105.56 & 115.78 & $21.824^{*}$ \\
\hline
\end{tabular}

\section{Daily feed intake}

The daily feed intake of rams was $118.90 \mathrm{~T}_{1}, 121.40 \mathrm{~T}_{2}$, 124.10 $\mathrm{T}_{3}$ and $128.70 \mathrm{~T}_{4} \mathrm{~g} / \mathrm{d} / \mathrm{h}$. The daily feed intake of the rams was significantly comparable in treatment one to three but significantly $(\mathrm{P}<0.05)$ different among the treatment. The rams fed $\mathrm{T}_{4}$ diets had significantly $(\mathrm{P}<0.05)$ higher dry matter intake, followed by rams fed $\mathrm{T}_{3}$ and $\mathrm{T}_{2}$ diets than those on $\mathrm{T}_{1}$. The feedintake showed a significant increase with increase level of molasses supplementation. The increase in DM intake could be as a result of molasses inclusion in the supplemental diet which had created a conducive environment in the rumen for the digestion and improvement in the rumen ecosystem Igene and Iboh (2004).

\section{Live weight gain}

The average daily live weight gain of rams fed urea and molasses treated maize cobs with cowpea husk were $86.56 \mathrm{~g} / \mathrm{h} / \mathrm{d}, 103.11 \mathrm{~g} / \mathrm{h} / \mathrm{d}, 105.56 \mathrm{~g} / \mathrm{h} / \mathrm{d}$ and $115.78 \mathrm{~g} / \mathrm{h} / \mathrm{d}$ for $\mathrm{T}_{1}$, $\mathrm{T}_{2}, \mathrm{~T}_{3}$ and $\mathrm{T}_{4}$ respectively. The live weight gain in the molasses inclusion were significantly $(\mathrm{P}<0.05)$ higher than the un-supplemented diets with molasses in $T_{1}$. Thisstudy demonstrated that supplementation or inclusion of graded level of molasses has tremendous advantage in weight gain of Yankasa rams over non molasses inclusion. This study is also in agreement with Ibrahim (2007) in an investigation on the effects level of cowpea vines supplementation to Yankasa sheep fed basal diet of Gamba grass.

Table 4: Nutrients intake of yankasa rams fed cowpea husk, urea and molasses treated maize cobs

\begin{tabular}{|l|r|c|c|l|}
\hline $\begin{array}{l}\text { Treatment } \\
\text { Parameter }\end{array}$ & $\mathrm{T}_{1}$ & $\mathrm{~T}_{2}$ & $\mathrm{~T}_{3}$ & $\mathrm{~T}_{4}$ \\
\hline $\mathrm{DMI}(\mathrm{g} / \mathrm{h} / \mathrm{d})$ & 118.84 & 120.44 & 123.14 & 127.74 \\
$\mathrm{OMI}(\mathrm{g} / \mathrm{h} / \mathrm{d})$ & 116.42 & 118.21 & 112.11 & 119.41 \\
$\mathrm{CPI}(\mathrm{g} / \mathrm{h} / \mathrm{d})$ & 119.69 & 121.29 & 123.99 & 128.59 \\
$\mathrm{CFI}(\mathrm{g} / \mathrm{h}$ d) & 119.66 & 121.26 & 123.96 & 128.56 \\
$\mathrm{ASHI}(\mathrm{g} / \mathrm{h} / \mathrm{d})$ & 119.70 & 121.33 & 124.00 & 128.68 \\
\hline
\end{tabular}

\section{Nutrient intake}

The rams fed $\mathrm{T}_{4}$ diets had significantly $(\mathrm{P}<0.05)$ higher dry mater intake, organic matter intake, crude protein intake, crude fibre intake and ash intake than those fed $T_{3}, T_{2}$ and $\mathrm{T}_{1}$ diets. Supplementation recorded high-numerical feed intake values due to the high level of molasses inclusion in the supplemented diet which improved crude protein intake and energy intake than those fed other treatment diets. This finding is in agreement with Qualaet al (2011). That the activity of the rumen microbes is improved by nitrogen supplemented diets leading to improved nutrients intake 


\section{International Journal of Science and Research (IJSR) ISSN (Online): 2319-7064 \\ Index Copernicus Value (2015): 78.96 | Impact Factor (2015): 6.391}

which enhance digestion in the gut. Also Tolera and Standstol (2000) observed that as supplementation increases nutrients intake by sheep fed a basal diet of maize Stover increases.

Table 5: The Nutrients digestibility of yankasa rams fed cowpea husk, urea and molasses treated maize cobs.

Treatment

\begin{tabular}{|c|c|c|c|c|}
\hline Parameters & $T_{1}$ & $\mathbf{T}_{2}$ & $T_{3}$ & $T_{4}$ \\
\hline DMD $\%$ & 47.88 & 52.92 & 53.94 & 59.43 \\
\hline $\mathrm{CPD}$ & 46.29 & 36.18 & 38.66 & 56.72 \\
\hline EED & 36.06 & 45.41 & 40.74 & 47.13 \\
\hline CFD & 32.72 & 33.65 & 59.01 & 65.71 \\
\hline ASHD $\%$ & 39.58 & 42.44 & 60.36 & 44.25 \\
\hline NFED $\%$ & 39.21 & 47,33 & 6354 & 29.69 \\
\hline
\end{tabular}

\section{Nutrient digestibility}

The crude protein digestibility was $46.29-56.72$. The results showed that rams fed $6 \mathrm{~kg}$ molasses and $4 \mathrm{~kg}$ urea $\left(\mathrm{T}_{4}\right)$ recorded the highest Crude Protein digestibility of $56.72 \%$ while the least $46.29 \%$ was recorded among rams in $\mathrm{T}_{1}$, while $\mathrm{T}_{2} 36.18 \%$ and $\mathrm{T}_{3} 38.66 \%$. This implies that ensiled urea treated fibrous material with fermentable carbohydrate could increase digestibility of the feed Nisaet al (2004), and there by improve voluntary intake Hogan (1996). One of the keys to profitable livestock production is to minimize the cost of producing marketable animal or animal products and these can be done through ensiling.

The crude fiber digestibility were from $32.72 \%, 33.65 \%$, $59.01 \%$; and $65.71 \%$ for $\mathrm{T}_{1}, \mathrm{~T}_{2}, \mathrm{~T}_{3}$ and $\mathrm{T}_{4}$ respectively, fiber in moderate quantities ensures proper functioning of the digestive system and gives a feeling of reflection, and that the essential of proper feeding is to feed a moderate quantities of crude fiber, because when excess occurs the digestion of all feeds constituents depressed total intake below nutritional needs.

The nitrogen free extract digestible of rams were $39.21-$ 29.69 , rams in diet $\mathrm{T}_{1} 39.21 \%, \mathrm{~T}_{2} 47.33 \%, \mathrm{~T}_{3} 63.54 \%$ and $\mathrm{T}_{4}$ $29.69 \% . \mathrm{T}_{4}$ had lowest value in the present study, though comparable to the value obtained and reported by Ibrahim (2007). The improved NFE might be due to incorporation of graded levels of molasses inclusion which supply soluble carbohydrates to the rumen microbes.

\section{Conclusion}

The inclusion of $6 \mathrm{~kg}$ molasses and $4 \mathrm{~kg}$ urea generally gave significantly $(\mathrm{P}<0.01)$ higher dry matter intake and live weight gain than the other treatment diets. This showed that molasses and urea can be utilize in improving the nutritive value of maize cobs in dry season when there is constant seasonal fluctuations in the quality and quantity of forages which results in marked seasonality in animals growth and productivity otherwise known as stair case growth.

\section{Recommendation}

It implies that ensiled urea treated fibrous material with fermentable carbohydrate increased digestibility of the feeds, and that energy protein balance of a ration enhances growth rate

\section{Conclusion}

The inclusion of $6 \mathrm{~kg}$ molasses and $4 \mathrm{~kg}$ urea generally gave significantly $(\mathrm{P}<0.01)$ higher dry matter intake and live weight gain than the other treatment diets. This showed that molasses and urea can be utilize in improving the nutritive value of maize cobs during dry season when there is constant seasonal fluctuations in the quality and quantity of forages which results in marked seasonality in animals growth and productivity otherwise known as stair case growth. It implies that ensiled urea treated fibrous material with fermentable carbohydrate increased digestibility of the feeds, andthat energy protein balance of a ration enhances growth rate

\section{Acknowledgement}

I want to extend my profound gratitude to my lecturers department of animal science and range management ModibboAdama University of Technology, Yola especially my supervisor Dr. Halilu D. Nyako and my class mate GabdoIdris Isa, AdamuBuba, NuruddeenAbubakar, KamaluddeenUsman and ElanaRimamsitwe for their contribution and constructive criticism.

\section{References}

\section{Books}

[1] A. A.Adabayo,A. L. Tukur: Adamawa State in map journal of applied science and management published by Parakeet, Yola. Nigeria Ltd, Pp.21-26,(1999).

[2] Association of AnalyticalChemist: Official Methods of Analysis, $13^{\text {th }}$ edition Washington D.C,Pp 1018,(1990).

[3] R.G.D. Steel,J.H. Tories: Principles and procedures of statistics. A biometrical approach: London McGrawHill. Book CompanyPp 195-233, (1980).

\section{Journals}

[4] A.A. Ademosum :Nutritive evaluation of Nigerian forage. The effects of stages of maturity on the nutritive value of panicum maximum (Guinea grass) Nigeria Agricultural Journals 10: Pp170-177,(1973).

[5] E.M .Agreheore :Nutritive and anti-nutritive value of some free legumes used in Ruminatelivestock nutrition in Pacific Island countries: Journal of South Pacific Agriculture 6(2) Pp 50-61, (2001).

[6] Asian Australian Journals of Animal Science : Vol. 19, Nos 5: Pp 705-712, (2006).

[7] I.Y. Dimas: Rumen degradation characteristic of some browse plants in Mayo-Belwa L.G.A Adamawa State M.Tech thesis (MAUTECT, YOLA)Pp 43-56, (2012).

[8] A.A.Fadiyimu, A.N. Fajemising, J.A.Alokan: Chemical composition of selected plantresidues and and their acceptability by W.A.O sheep. Livestock for Rural Development, V. 23:12. Pp 21-24, (2011).

[9] J. Hogan: Feed intake ruminant nutrition and production in the tropics and sub tropics:Pp47 (ACIAR: Canberra. ACT),(1996). 


\section{International Journal of Science and Research (IJSR) \\ ISSN (Online): 2319-7064}

Index Copernicus Value (2015): 78.96 | Impact Factor (2015): 6.391

[10] B.G.Ibrahim: Supplementary feeding of cowpea vines to Yankasa sheep offered a basal diet of guinea grass. Unpublished .Tech thesis, submitted to the Department of animal science and Range management, MAUTECH Yola. Pp 67, (2007).

[11]M.A. Khan, M.Sarwar, M.Nisa,M.S. Khan: Feeding value of urea treated corncobs ensiled with or without enzose (corn dextrose) for lactating cross cows, Asian Australian journal of animal sciences 17:Pp 1093-1097, (2004)

[12] M.Nisa, R.Sarwar,MA. Khan: Influence of ad-libitum feeding of urea treated wheat straw with or without corn steep Lquor on intake, in situ, digestion Kinetics. Nitrogen metabolism and nutrients digestion in Nilin Ravi buffalo bulls. Australian journals of agricultural research Pp 55:225-234, (2004).

[13]I.D. Quala,M. S.Yahaya, A.Midau, S. B.Aju,Y.M.Mukar,H.D. Nyako: Assessment of digestibility of inter cropped Sorghum Stover with legumes (Groundnuts) Global Journal of science frontier research 11 (3):Pp 45-54, (2011).

[14]R. A. Joseph: The Effects of Cowpea Husk Supplementation on the Performance of Yankasa rams fed Gmelina leaves (Gmelinaarborea), Unpublished M.Techthesis, submitted to the Department of Animal science and Range Management FUTY, Yola. Pp20,(2007).

[15] M.Sarwar, M.A.Khan,M.Nisa: Effects of organic acids or fermentable carbohydrate on digestibility and Nitrogen utilization in Nili - Ravi, buffalo bulls. Australian journal of Agricultural research 55:223228,(2004).

\section{Conference Proceeding}

[16]F.U.Igene, S.O.Iboh: Growth performance and Hematological responses of cockerel chicks fed diets containing different levels of rice offals as replacement for wheat offals. Proceedings of the $9^{\text {th }}$ Annual Conference of animals science Association of Nigeria, pp. 20-22 (2004). 